\title{
$X: 48416735-48439629$
}

National Cancer Institute

\section{Source}

National Cancer Institute. X: 48416735-48439629. NCI Thesaurus. Code C42461.

Physical location of HDAC6_Gene 